\title{
NUMERICAL SIMULATION OF THE BEARING CAPACITY OF A STRIP FOOTING ON REINFORCED SAND
}

\author{
Fang-Le PENG ${ }^{1}$, Fumio TATSUOKA ${ }^{2}$, M. S. A. SIDDIQUEE ${ }^{2}$, Nozomu KOTAKE ${ }^{3}$ \\ and Ching-Chuang HUANG
}

\begin{abstract}
The load-settlement behaviour and bearing capacity of a strip footing on reinforced sand was simulated by a nonlinear elasto-visco-plastic FEM analysis incorporating an elasto-viscoplastic constitutive model for sand that was developed to have a stress path-independent work-hardening parameter based on the modified plastic strain energy concept. The constitutive model has been modified to take into account the nonlinear viscous property of sand based on a three-component model consisting of a hypo-elastic component connected in series to a combination of a non-linear inviscid and viscous components connected to each other in parallel. The model ground was made of air-dried dense Toyoura sand, which was either unreinforced or reinforced with different lengths, numbers of layers and vertical spacings of layers of linear, tensile reinforcing members placed horizontal beneath a strip footing. Load-settlement relationships obtained by the FEM analysis were well comparable with those from the physical experiment. Although the peak footing load obtained by the FEM analyses was slightly larger than the measured value, the effects of reinforcing patterns and progressive failure of model ground with a development of shear bands observed in the tests were simulated very well.
\end{abstract}

Keywords: Reinforced sand, bearing capacity, FEM, Work-hardening, elasto-viscoplastic model, stress-strain relation

\section{INTRODUCTION}

Tatsuoka et al. (1991), Siddiquee (1994) and Kotake et al. (1997) examined the effects of different assumptions for constitutive relations on the bearing capacity of footing on sand in the FEM analysis considering strain localization based on the strain-hardening model. In their results, the pre-peak footing settlement measured in the physical experiments was always underestimated. Kotake (1998) and Peng et al. (1998, 2000) considered that this discrepancy is due, at least partly, to that the assumption as to the hardening parameter was inadequate and, for this reason, shear strains for stress paths traced in the ground were underestimated. The FEM analysis also revealed that typical stress paths in the ground in the yielding zones below the footing are very similar to anisotropic compression stress paths with high stress ratios, which are considerably different from those in the conventional triaxial and plane strain compression tests at constant confining pressure. This paper reports results from a numerical simulation of a series of laboratory model tests performed to evaluate the bearing capacity of reinforced sand (Huang and Tatsuoka, 1990). This simulation was based on a strain energy-based elasto-viscoplastic constitutive model that was developed to overcome the above-mentioned drawback with the previous simulation. The new constitutive model considers the stress history- and stress path-dependency of the deformation characteristics of sand. By comparing the results from the FEM analysis with those from the physical experiments, it is shown that not only the load-settlement characteristics and bearing capacity but also strain fields in the ground measured in the physical experiments can be simulated very well.

\section{MODEL TESTS}

Fig. 1 shows the setup of these laboratory tests performed under plane strain conditions. In the model tests, different reinforcing patterns of reinforced soil foundation were employed to evaluate the effects of the length, the number of layers, the horizontal spacing and the stiffness and rupture strength of reinforcement (Huang and Tatsuoka, 1990). Reinforcing strips, having a thickness of $0.5 \mathrm{~mm}$ and a width of $3 \mathrm{~mm}$, were made of phosphor bronze. Their surfaces were made rough by gluing the particles of the model sand. Some reference tests were conducted on unreinforced sand ground. Each model ground $(183 \mathrm{~cm}$ in width, $40 \mathrm{~cm}$ in length and 74

${ }^{1}$ 正会員、(株) 白石（元東京大学)、技術本部開発技術部（ $\overline{\%} 101-8588$ 東京都千代田区神田岩本町 $1-14$ )

2 正会員、東京大学工学部、土木工学科、教授 ( $1113-8656$ 東京都文京区本郷 7-3-1)

${ }^{3}$ 正会員、東洋建設（株）、土木本部土木設計部（ \% 101-8463 東京都千代田区神田錦町 3-7-1）

4 正会員 台湾成功大学、土木工学科、教授 

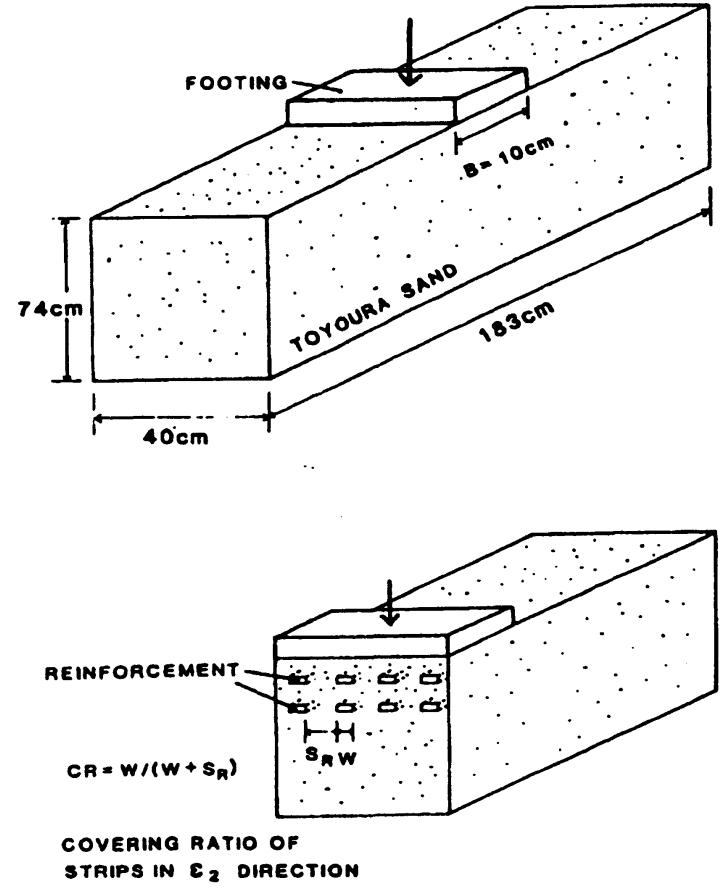

Fig. 1 A set of laboratory model test

$\mathrm{cm}$ in depth) was produced by pluviating air-dried Toyoura sand from a slit of a hopper at a controlled fall height into a sandbox. By this method, homogeneous, dense sand models having very similar relative density values in a range of $D_{r}=$ $80-86 \%$ were obtained. On the outer surface of a thin latex membrane used for lubrication of the lateral inner surfaces of the sand box, $1 \mathrm{~cm}$-square meshes were printed. Displacement fields on the intermediate principal strain plane of each model ground were obtained from displacements at the nodal points of the meshes. A rigid footing with a rough base was used, which was $10 \mathrm{~cm}$ wide and $39.8 \mathrm{~cm}$ long and guided against tilting and translation, was loaded at a controlled displacement rate between 0.1 and $0.2 \mathrm{~mm} / \mathrm{min}$. Distributions of normal and shear stresses at the central third of the footing base were measured by using 5 load cells, each of which measured local normal and shear forces separately.

In the present study, results from the three groups of physical model tests described in Fig. 2 and explained below were analyzed, in which $\boldsymbol{L}$ is a reinforcement length, $\boldsymbol{B}$ is the footing width, $\boldsymbol{n}$ is the number of reinforcement layers and $\boldsymbol{d}=0.3 B$ :

Group-a: to study whether short reinforcement layers having a length $L$ that is the same as the footing width $B$ can reinforce the ground effectively. The effects of the number of layers of the short reinforcement with $\mathrm{L}=\mathrm{B}$ were evaluated. Three tests on unreinforced sand were performed as reference tests.

Group-b: to study into the effects of the length of reinforcement, $\mathrm{L}=\mathrm{B}, 2 \mathrm{~B}, 3.5 \mathrm{~B}$ and $6 \mathrm{~B}$, in the case of the number of layers $n=3$ :
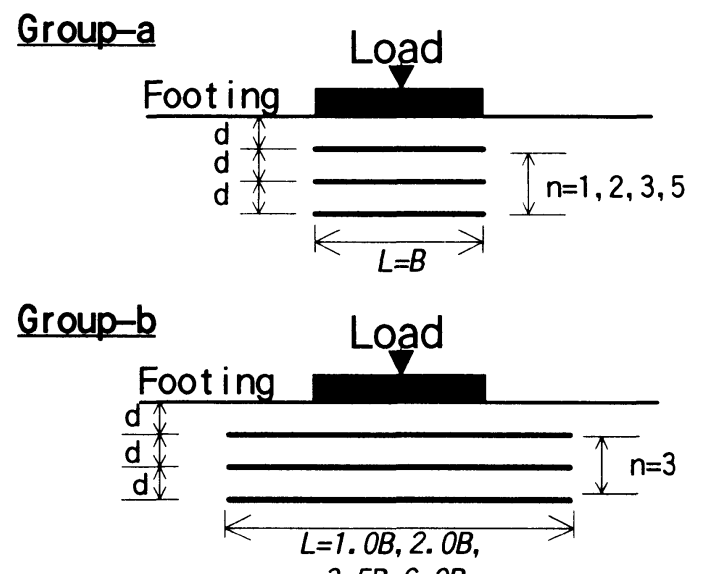

3. $5 B, 6 . O B$

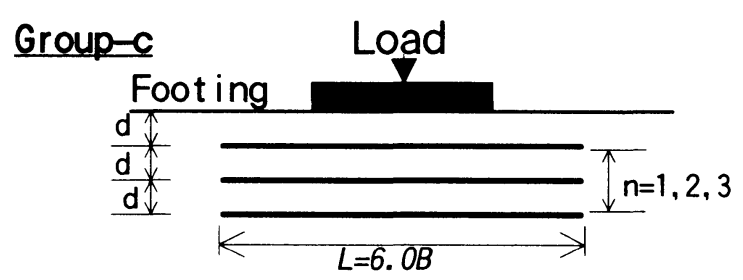

Fig. 2 Groups of laboratory model tests

Group-c: to study into the effects of the number of layers, $n=1$, 2 and 3 , in the case of long reinforcement of $L=6 B$.

\section{FEM DETAILS}

\subsection{FEM Model for Sandy Ground}

The FEM mesh used in the present study is shown in Fig. 3, which is only a half domain of the physical model ground. The ground was discretized into four-noded quadrilateral plane elements. The vicinity of the footing was discretized into fine elements $(1.0 \mathrm{~cm} \times 1.0 \mathrm{~cm}$ square) to capture the failing deformation modes observed in the physical experiment. The total numbers of the elements and the nodal points are 840 and 893 , respectively. Rollers were placed vertical along the footing centerline (i.e., the axis of symmetry), while rollers were placed horizontal and vertical along the bottom and the other lateral boundaries of the analysis domain, respectively.

The initial stress state of the homogeneous level ground was assumed as the $K_{\sigma}$-stress condition that is given as; $\sigma_{h o}=K_{o} . \sigma_{v o}$ and $\sigma_{v o}=\gamma_{d} \cdot h$, where $\sigma_{v o}$ and $\sigma_{h o}$ are the initial vertical and horizontal stresses, respectively, and $h$ is the depth of the gauss point of a concerned plane element. A $K_{\sigma}$-value equal to 0.34 was used which was obtained by substituting the average void ratio of the model grounds, $e_{\bar{\sigma}}=$ 0.66 , into the empirical equation; $K_{\sigma}=0.52 e_{0}$. This empirical equation was obtained from stress-strain tests on air-pluviated 


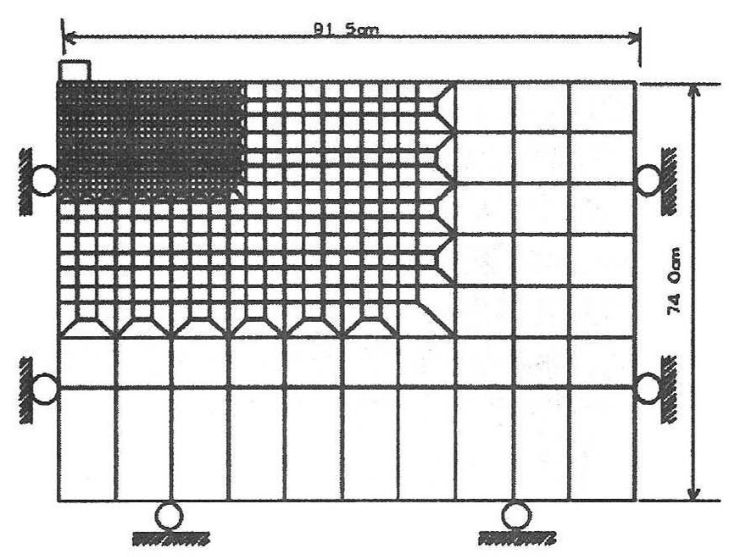

Fig. 3 Finite element mesh for simulation

Toyoura sand by means of a double-cell triaxial apparatus (Okochi and Tatsuoka, 1984). In this FEM analysis, an average unit weight of sand $\gamma_{d}=15.58 \mathrm{kN} / \mathrm{m}^{3}$ and an average initial void ratio $e_{0}=0.66$ were used as representative values. This average value of $\gamma_{d}$ was therefore slightly different from the value of each physical model ground, which ranged from 15.40 to $15.65 \mathrm{kN} / \mathrm{m}^{3}$.

\subsection{Constitutive Model for Sand}

In the present study, the elasto-plastic constitutive model for sand which was originally developed by Siddiquee (1994) and Siddiquee et al. (1995) was modified based on the modified plastic strain energy concept, represented by a unique relationship between the modified plastic strain energy and a stress parameter, which is independent of stress history (Peng, 2000; Peng et. al, 2000, 2001). The modified plastic strain energy concept was developed based on results from a series of drained plane strain compression tests along various stress paths on saturated dense Toyoura sand with accurate stress and strain measurements (Yasin and Tatsuoka, 2000). In the constitutive modelling, the inherent and stress system-induced cross-anisotropic elasticity is considered, based on a series of laboratory stress-strain tests with respect to anisotropic elastic deformation properties of sand (Hoque and Tatsuoka, 1998). The proposed model is coupled with an isotropically work-hardening and softening, non-associated, elasto-plastic material description. The yield function and the plastic potential function are of, respectively, Mohr-Coulomb and Drucker-Prager type. It is assumed that the deformation of a given sand element under uniform boundary stress conditions is homogeneous in the pre-peak regime, while strain localization into a shear band starts suddenly at the peak stress state (Tanaka and Sakai, 1993). The smear method, which is similar to the one proposed by Pietruszczak and Mroz (1981), was employed to incorporate strain localization. Unlike their

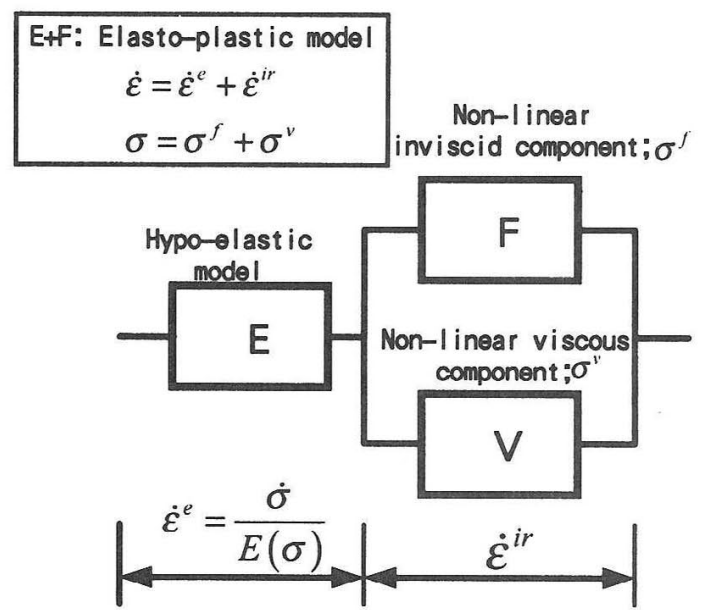

Fig. 4 Elastic-visco-plastic three component model

method, however, no direction of shear banding was specified. The constitutive model is capable of simulating the effects on the deformation characteristics of stress history, stress path and pressure level. The details of the proposed sand model have been reported in several previous papers by the authors (Yasin and Tatsuoka, 2000; Peng, 2000; Peng et al, 2000, 2001; Tatsuoka et al, 2000; Sidiquee.et al. 2001).

Fig. 4 shows the three-component model that was developed to simulate the time-dependent stress-strain behaviour of geomaterials (Di Benedetto et al., 2001; Tatsuoka et al., 2001). In the framework of the three-component model, the conventional elasto-plastic model consists of the two components $(\mathrm{E}+\mathrm{F})$ depicted in Fig. 4, where $\mathrm{E}$ means the hypo-elastic component, while $\mathrm{F}$ means the non-linear inviscid component. For the latter component, the stress-strain relation is inviscid with the stress is being a unique function of irreversible strain.

In the present study, the three-component model $(\mathrm{E}+\mathrm{F}+\mathrm{V})$ was employed. Di Benedetto et al. (2001) and Tatsuoka et al (2001) showed that the three-component model can simulate very well the time-dependent stress-strain property of sand, such as; a) effects of gradual and stepwise changes in the strain rate and different constant strain rates on monotonic loading stress-strain behaviour; b) creep, where the irreversible strain rate continuously decreases towards zero at a constant stress; c) stress-relaxation, where the stress decreases while the irreversible strain rate continuously decreases towards zero at a constant total strain with negative elastic strain increments and positive irreversible strain increments, and so on.

In the modified constitutive modelling, the following properties were incorporated:

a) the inviscid pre-peak stress-strain relation with work-hardening elasto-plastic deformation characteristics; 
b) a non-associated flow for irreversible strain;

c) anisotropic strength and deformation;

d) pressure level-dependency of strength and deformation;

e) post-peak work-softening;

f) shear banding with a characteristics shear band width (i.e., particle size effect);

g) time-dependent deformation properties of sand.

The FEM code incorporating the above-proposed model is validated by a direct comparison between the numerical and physical test results on one element of sand (Siddiquee and Tatsuoka 2001). In the present simulation, the footing was loaded at a controlled displacement rate equal to $0.15 \mathrm{~mm} / \mathrm{min}$, referencing to the physical model test. It was found that the creep deformations in each simulation case were very small, not affecting the footing load value. Despite the above, the numerical solution by the non-linear FEM analysis became substantially stable by introducing viscous effects.

\subsection{Modeling of Reinforcement}

The layers of reinforcing strips were modeled by beam elements. The strips in each layer, arranged three-dimensionally, were replaced with a two-dimensional planar member, having an equivalent stiffness. The axial and bending stiffness of the plate was equal to the respective average value of the total strips in each layer. For example, a reinforcement layer consisting of 24 strips when a covering ratio equal to $18 \%$ had an cross-sectional area equal to $0.009 \mathrm{~cm}^{2}$ and a moment inertia equal to $1.875 \times 10^{-6} \mathrm{~cm}^{4}$ per unit length in the $\varepsilon_{2}$ direction. The reinforcing strips were simply assumed to be linear elastic based on the measurements on stress-strain relationships of the strip used in the physical experiments. The Young's modulus of the reinforcement (phosphor bronze) was equal to $1.22 \times 10^{8} \mathrm{kN} / \mathrm{m}^{2}$. In this present study, no interface elements were used since neither pronounced slippage between sand and reinforcement nor pull-out failure of reinforcement was observed in the physical model tests.

\subsection{Nonlinear Solution Technique}

A set of non-linear equations was solved by the dynamic relaxation (DR) technique (Tanaka et al., 1988), which has a reputation in solving highly non-linear equations, especially for high friction angle materials as used in the present case. The integration of the elasto-plastic equation was done by the return mapping scheme (Ortiz and Simo, 1986), which is a first order approximated Euler backward integration. A FEM code with an optimized dynamic relaxation solver developed by Tanaka and Kawamoto (1988) was used. Four-node quadrilateral elements along with reduced integration (Zienkiewicz et al., 1971) were used to improve the bounds of solution in the pseudo-equilibrium for sand as a highly non-linear material. To prevent any probable hourglass mode, the anti-hourglass

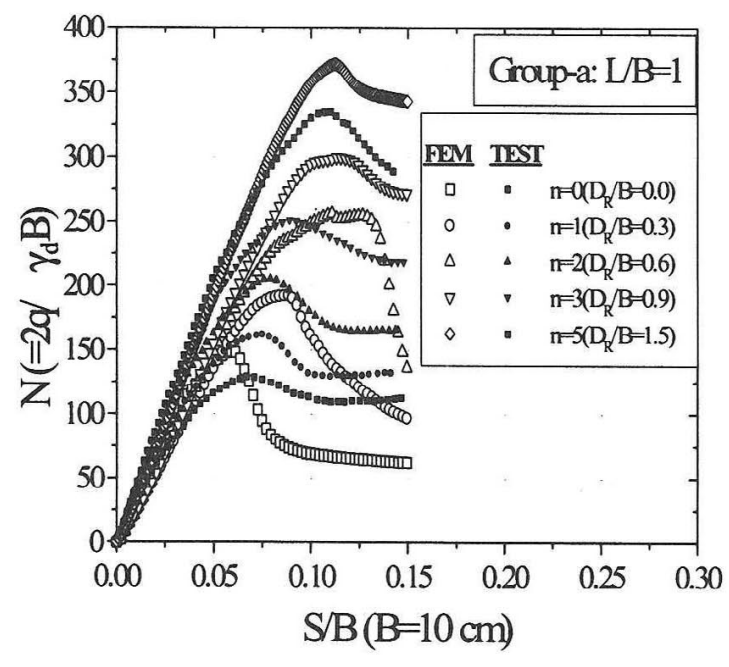

Fig. 5 Normalized load-settlement relations for Group-a

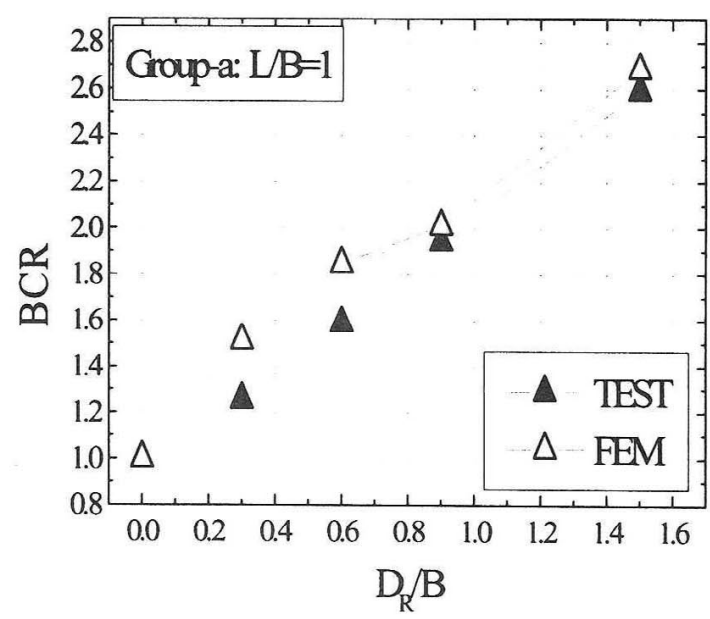

(a) $\mathrm{BCR} \sim \mathrm{D}_{\mathbb{R}} / \mathrm{B}$

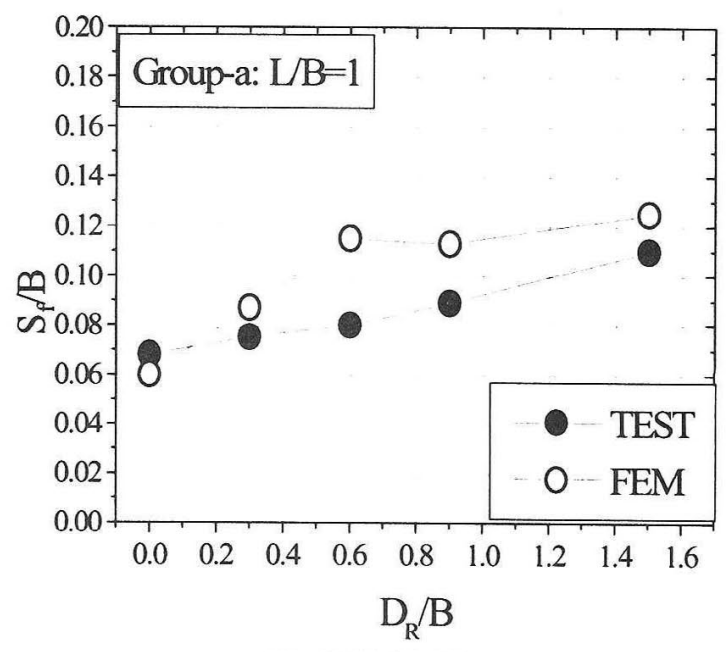

(b) $\mathrm{S}_{\mathbb{A}} / \mathrm{B} \sim \mathrm{D}_{\mathbb{R}} / \mathrm{B}$

Fig. 6 Effects of the number of short reinforcement layers 
scheme proposed by Flanagan and Belytschko (1981) was adopted. Following an elastic stiffness approach of the scheme, a very small elastic stiffness of the actual material elastic stiffness at the start of loading was added to the non-linear system as hour-glass resisting nodal forces whenever any soil element starts to form a hour-glass mode. The detail is described in Siddiquee et al. (1995), Kotake et al. (2000) and Peng et al. (2000).

\section{RESULTS AND DISCUSSION S}

\subsection{Effects of Number of Short Reinforcement Layers}

Fig. 5 compares the normalized load-settlement relationships obtained from the physical tests and the FEM analysis for Group-a. Figs. 6a and $b$ summarise the effects of the depth of reinforced zone $\left(D_{R} / B\right)$, which is proportional to the number of reinforcement layer $(n)$, and on the bearing capacity ratio, $B C R=$ Reinforced peak load / unreinforced peak load, and the relative footing settlement at peak load $(S / B)$. The following trends of behaviour may be seen:

1) The overall load-settlement relation observed in the physical tests is very well simulated for both unreinforced and reinforced models. So, the effects of the depth of reinforced zone (or the number of reinforcement layers) on the peak footing load and the footing settlement at the peak footing load are simulated very well.

2) Despite the above, the FEM analysis exhibits generally slightly larger peak load compared with that from the physical test. This could not be attributed partly to that the reinforcing strips were modelled as a two-dimensional planar reinforcement and no specific interaction effects at the interface between the soil and the reinforcement were considered. This is because similar overestimation of load is observed with both unreinforced and reinforced model grounds.

\subsection{Effects of Reinforcement Length}

Fig. 7 compares the normalized load-settlement relationships obtained from the physical tests and the FEM analysis, while Figs. 8a and b summarise the effects of reinforcement length $(\mathrm{L})$ on the bearing capacity ratio $(B C R)$ and the relative footing settlement at peak load $\left(S_{f} / B\right)$ for Group-b. In this case, reinforcement layers were placed being extended laterally beyond the footing width so as to expect anchoring effects outside the potential failure zone. The following trends of bchaviour may be noted:

1) As with the case of Group-a, the overall load-settlement relation observed in the physical tests is very well simulated for both unreinforced and reinforced models.

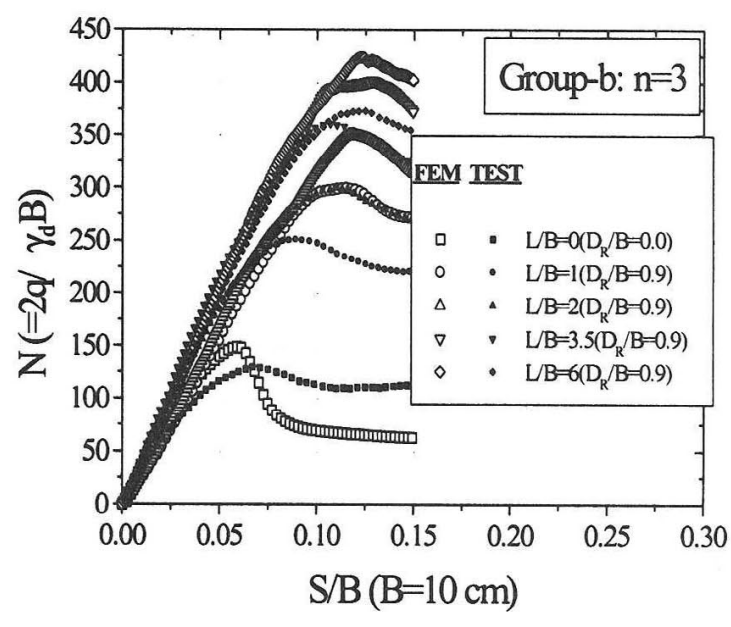

Fig. 7 Normalized load-settlement relations for Group-b

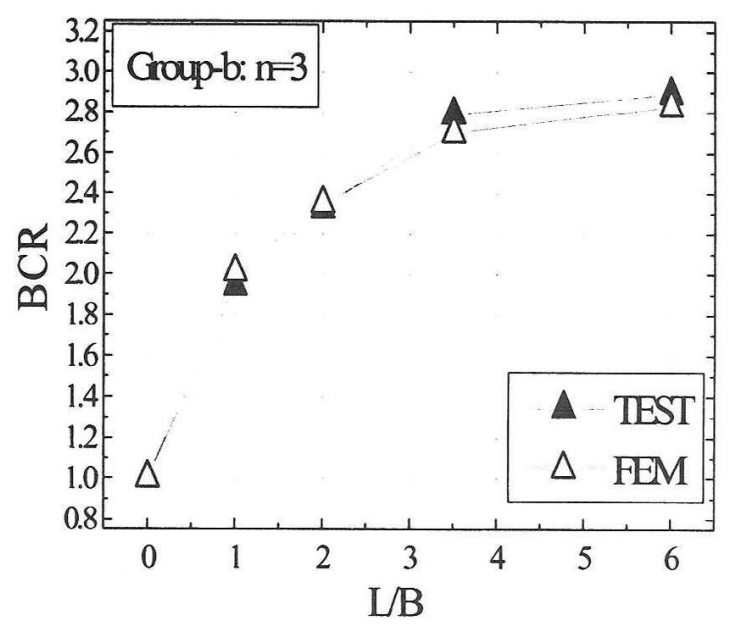

(a) BCR L/B

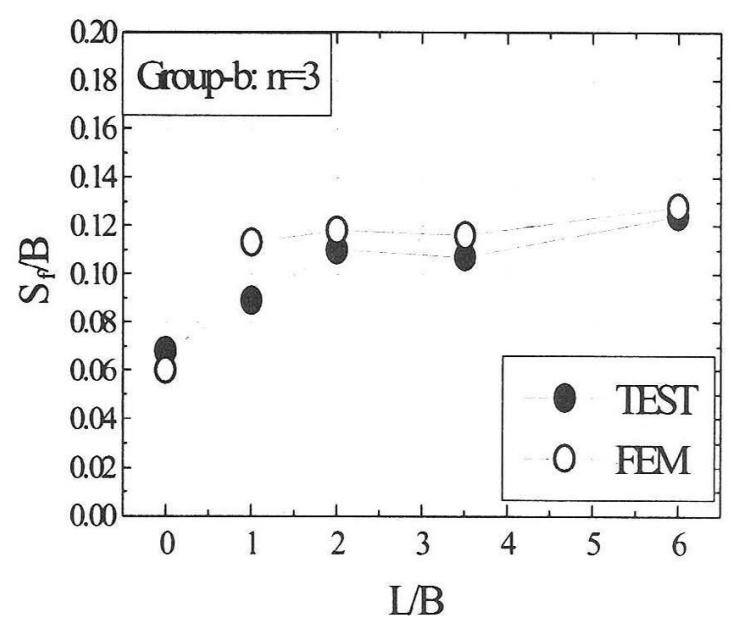

(b) $S_{\mathbb{f}} / \mathrm{B} \sim \mathrm{L} / \mathrm{B}$ 
2) In the physical tests, the effects of reinforcement length $L$ increases at a decreasing rate for $L$ larger than $B$. In particular, the increase in the $B C R$ value when $L / B$ increases from 3 is essentially zero. Correspondingly, the settlement of footing at the peak footing load does not increase noticeably when $L$ increases exceeding $B$. The FEM analysis simulates very well these trends of behaviour.

3) However, it is also seen that the FEM analysis exhibits peak footing load that is slightly larger than those from the physical tests.

\subsection{Effects of Number of Long Reinforcement Layers}

Fig. 9 compares the normalized load-settlement relationships obtained from both the physical tests and the FEM analysis for Group-c, while Figs. 10a and b summarise the effects of the number of the longer reinforcement layers (n) (i.e., the effects of the depth of reinforced zone, $D_{R} / B$ ) on the bearing capacity ratio $(B C R)$ and the relative settlement at peak load $(S / B)$. It may be seen that the bearing capacity increased with the increase in $n$ in a manner similar to that observed in the case of $L / B=1$ in Group-a (Figs. 5 and 6). The increase in the bearing capacity with the increase in the number of short reinforcement layers seen in Group-a $(L / B=1)$ is mostly due to the "deep-footing" effects, while the difference between Groups a and c can be attributed to the "wide-slab" effects by longer reinforcement $(L / B=6)$. The physical test results indicate that the "deep-footing effect" is rather dominant in the behaviour in in Group-c $(L / B=6)$. Such trends as above can also be seen in the results from the FEM analysis.

\subsection{Insight into Localization Characteristics and Shear Banding}

Figs. 1la and $\mathrm{b}$ show the contours of maximum shear strain $\gamma$ $\max \left(=\varepsilon_{1}-\varepsilon_{3}\right)$ at peak footing load in the ground obtained from the representative physical tests and their FEM analysis. It may be seen by comparing each pair of figures that the FEM analysis simulates rather accurately the results from the physical tests, in particular the following trends of behaviour:

1) For the unreinforced ground, a shear band started developing from the edge of the footing and formed a well-defined wedge beneath the footing;

2) For the reinforced case of $\mathrm{n}=1$ and $L / B=1$, only small strains were induced inside the reinforcing zone beneath the footing and shear bands were intensely formed along the lateral faces of the reinforcing zone. In addition, the strain in the zone beneath the reforming zone was very large, which is similar to the one seen beneath the rigid deep footing

3) For the case of $n=3$ and $L / B=2$, the reinforcement layers spread the footing load more widely in the ground, while relatively large tensile forces were mobilized in the reinforcement along corresponding to the deformation of

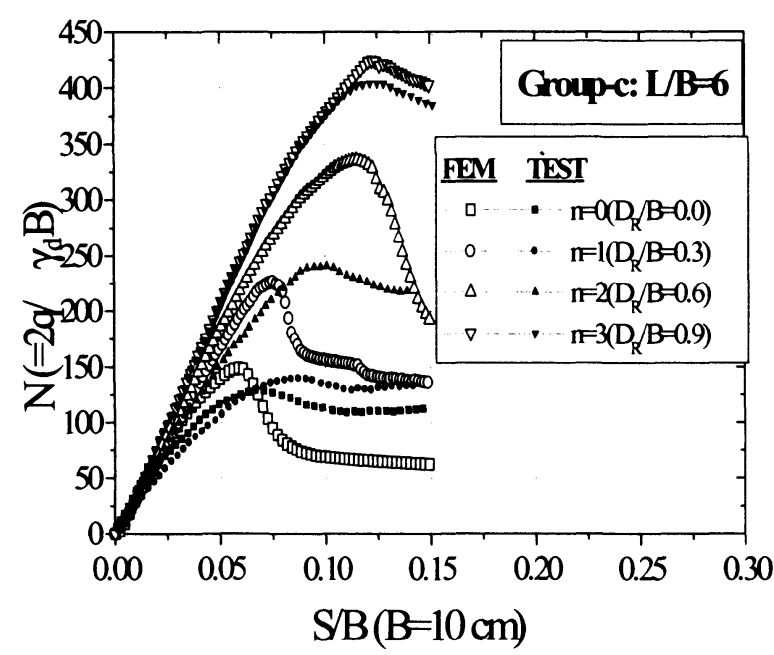

Fig. 9 Normalized load-settlement relations for Group-c

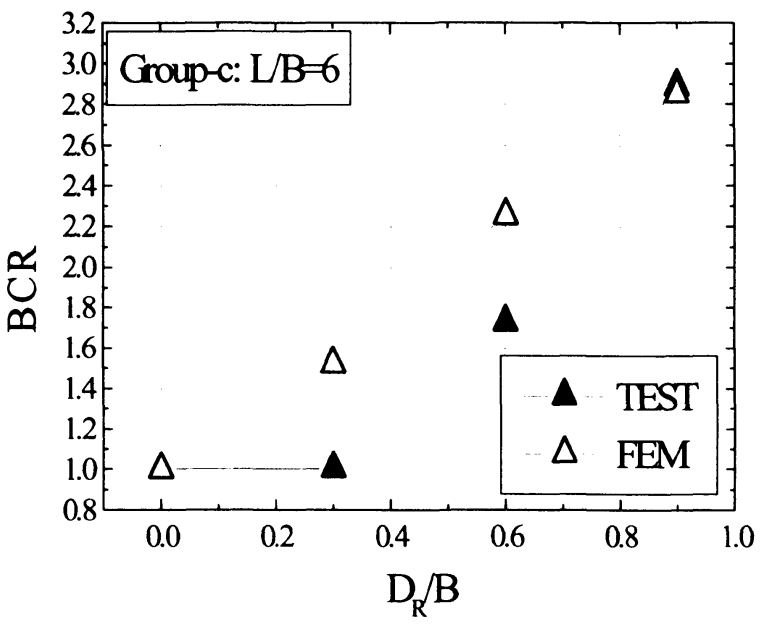

(a) $B C R \sim D_{R} / B$

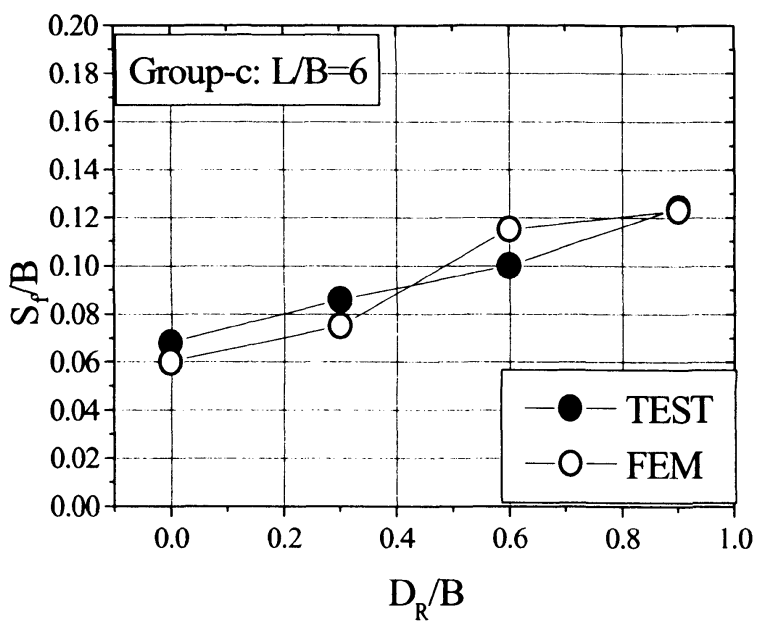

(b) $\quad S_{\mathrm{P}} / \mathbf{B} \sim D_{R} / B$

Fig. 10 Effects of the number of long reinforcement layers 

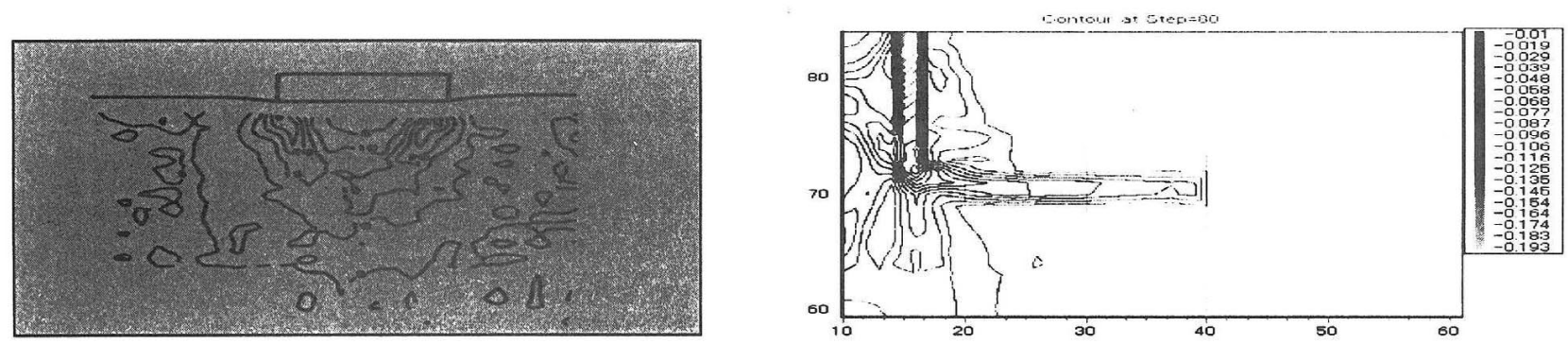

i) Unreinforced Case
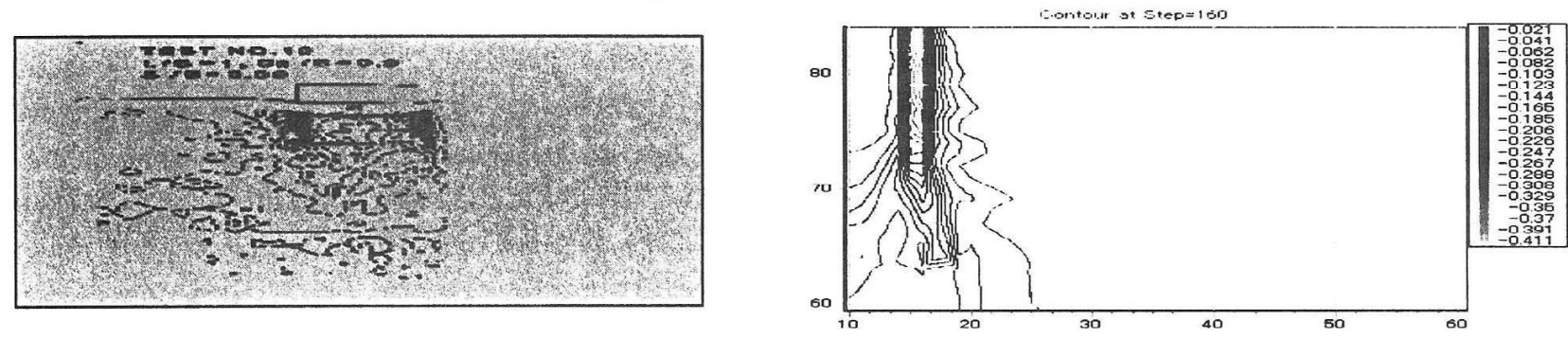

ii) Reinforced with $L / B=1$ and $n=3$
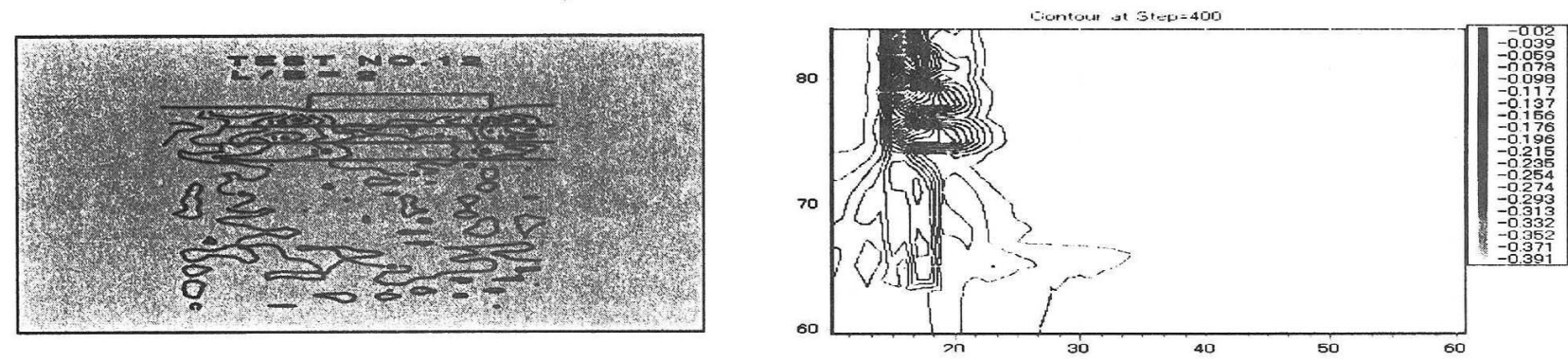

iii) Reinforced with $L / B=2$ and $n=3$

(a) Experiment

(b) FEM

Fig. 11 Comparison of the maximum shear strain at the peak states between the physical experiments and the FEM analyses

sand, restraining the shear band development in the reinforcing zone. Despite the diffusion of the shear bands due to the reinforcing effects in the reinforced zone, a wedge was formed beneath the reinforcing zone.

\section{CONCLUSIONS}

It was studied whether the bearing capacity characteristics of a strip footing on reinforced sand observed in physical tests can be simulated by FEM analysis incorporating a non-linear elasto-viscoplastic constitutive model. The following conclusions can be drawn from the above:

(1) The proposed FEM analysis method could simulate well the footing load-settlement relations and bearing capacity of a strip footing on both unreinforced and reinforced sand ground, although the peak footing load obtained by the FEM analyses was slightly larger than the measured value in the physical tests.

(2) The FEM analysis could simulate very well the effects of different arrangements of reinforcement (i.e., different numbers of reinforcement layers and the length of reinforcement) and the failure modes and strain localization observed in the physical tests.
(3) The introduction of viscous effects on the stress-strain property of sand resulted in very stable simulations of the footing load-settlement relations including peak footing states and post-peak regimes, although the viscous component in the total footing load was negligible.

\section{REFENERCES}

1) Di Benedetto,H., Tatsuoka,F. and Ishihara,M.: Time-dependent shear deformation characteristics of sand and their constitutive modelling, Soils and Foundations, 2001 (accepted).

2) Flanagan, D. P. and Belytschko, T.: A uniform strain hexahedron and quadrilateral with orthogonal hourglass control, Int. J. Numer. Methods Eng., Vol.17, pp.679-706, 1981.

3) Huang, C-C. and Tatsuoka, F.: Bearing capacity of reinforced horizontal sandy ground", Geotextiles and Geomembranes, 9(51-82), pp. 236-267, 1990.

4) Kotake, N., Peng, F. L., Tanaka, T., Higuchi, T., Shida, Y., Yanagisawa, H. and Tatsuoka, F.: Numerical simulation of plane strain compression tests on large geogrid-reinforced sand specimens, Geosynthetics Engineering Journal, 
JCIGS, Vol. 12, pp. 36-44, 1997.

5) Kotake, N.: FEM simulation of deformation and failure of reinforced soil, Doctoral Thesis, The University of Tokyo, Japan, 1998.

6) Kotake, N., Tatsuoka, F., Tanaka, T., Siddiquee, M. S. A. and Yamauchi, H. : An insight into the failure of reinforced sand in plane strain compression by FEM simulation, Soils and Foundations, pp. 39-5, 1999.

7) Ortiz, M. and Simo, J.C.: An analysis of a new class of intergration algorithms for elastoplastic constitutive relations", Int. J. Numer. Methods Eng., Vol..23, .pp. 53-366, 1986.

8) Okochi, Y. and Tatsuoka, F.: Some factors affecting Ko-values of sand measured in triaxial cell, Soils and Foundation, Vol. 24, No. 3, pp. 52-68, 1984.

9) Peng, F. L., Kotake, N., Hirakawa, D., Okajima, S. and Tatsuoka, F.: FE analysis of plane strain compression tests on geogrid-reinforced sand, Geosynthetics Engineering Journal, JCIGS, Vol. 13, pp. 218-227, 1998.

10) Peng, F. L.: Constitutive Modeling and Finite Element Analysis of Reinforced soils, Ph. D. Thesis, The University of Tokyo, 2000.

11) Peng ,F. L., Kotake, N, Tatsuoka, F., Hirakawa, D. and Tanaka, T.: Plane strain compression behavior of geogrid-reinforced sand and its numerical analysis, Soils and Foundations, Vol. 40, N0. 3, pp. 55-74, 2000.

12) Peng, F. L., Tatsuoka, F., Siddiquee, M. S. A., Kotake, N., and Yamauchi, H: FEM simulation of Failure of reinforced sand based on a new work-hardening constitutive model, Geosynthetics Engineering Journal, JCIGS, Vol. 15, pp. 166-175, 2000.

13) Peng, F. L., Tatsuoka, F., Siddiquee, M. S. A. and Yasin, S. J. M.: A new plastic model for granular materials, Proc. of the $10^{\text {th }}$ International Conference on Computer Methods and Advances in Geomechanics (Desai et al. eds), Arizona, Vol. 1, pp. 383-388, 2001.

14) Siddiquee, M. S. A.: Finite Element analysis of settlement and bearing capacity of footing on sand, Doctor's
Thesis, The University of Tokyo, 1994.

15) Siddiquee, M.S.A., Tanaka, T. and Tatsuoka, F.: Tracing the equilibrium path by dynamic relaxation in materially non-linear problems, International Journal for Numerical and Analytical Methods in Geomechanics, Vol.19, pp.749-767, 1995.

16) Siddiquee, M. S. A. and Tatsuoka, F.: Modeling time-dependent stress-strain behavior of stiff geo-materials and its application, Proc. of the $10^{\text {th }}$ International Conference on Computer Methods and Advances in Geomechanics (Desai et al. eds), Arizona, Vol. 1, 2001.

17) Tanaka, T. and Kawamoto, O.: Three dimensional finite element collapse analysis for foundations and slopes using dynamic relaxation, Proc. of Numerical Methods in Geomechanics, Insbruch, pp. 1213-1218, 1988.

18) Tanaka, T. and Kawamoto, O.: Numerical modelling for softening with localization, Ingenieur-Archiv, 1990.

19) Tatsuoka, F., Molenkamp, F., Torii, T. and Hino, T. Behaviour of lubrication layers of platens in element tests, Soils and Foundations, Vol.24, No.1, pp.113-128, 1984.

20) Tatsuoka, F. Okahara, M., Tanaka, T., Tani, K., Morimoto, T., and Siddiquee, M.S.A.: Progressive failure and particle size effect in bearing capacity of a footing on sand, Geotechnical Engineering Congress (McLean et al. eds.), Vol. 2, pp.788-802, 1991.

21) Tatsuoka, F., Siddiquee, M. S. A., Park, C. -S., Sakamoto, M. amd Abe, F.: Modeling stress-strain relations of sand, Soils and Foundations, Vol. 33, No. 2, pp. 60-81, 1993.

22) Tatsuoka, F., Ishihara, M., Di Benedetto, H. and Kuwano, R.: Time-dependent shear deformation characteristics of geo-materials and their simulation, Soils and Foundations, 2001 (submitted).

23) Zienkiewicz, O. C., Taylor, R. L. and Too, J. M.: Reduced integration technique in general analysis of plates and shells, Int. J. Numer. Methods Eng., Vol. 3, pp. 275-290, 1971.

\title{
補強砂地盤の支持力破壊の数值解析
}

\author{
彭 芳楽・龍岡 文夫 -M.S.A. Siddiquee - 小竹 望・黄 景川
}

フーチング直下に線状の引張補強材を水平に配置した密な空気乾燥豊浦砂の模型水平地盤の平面ひずみ支持力実験を対象とし て、修正エネルギー硬化モデルを用いた弾塑性 FEM 解析を適用した。砂のモデルは、応力履歴に依存しない修正された塑性ひずみ エネルギーに基づく硬化則を用いた等方硬化・軟化非関連流れ則による弾塑性モデルであり、砂の変形の応力履歴・応力経路の依 存性、弾性係数の異方性、内部摩擦角の異方性及び拘束圧・初期密度の依存性、せん断帯の発生ひずみの局所化を考虑した。また、 砂の応力・ひずみ関係の構成式における粘性効果を、三要素モデルを基本としたモデルで定式化した。補強材の長さ、層数、間隔 を変化させた種々のケースと無補強の模型実験を解析した。FEM 解析で得られた荷重〜沈下量関係は、実験結果よりピーク荷重が少 し大きい傾向を示したが、補強材の配置が補強効果に与える影響は実験結果とほほ同様な傾向を示した。また、せん断帯の発生状 況の比較から、実験で確認された破壊形態がFEM 解析により良く再現されることが認められた。 